\title{
Maatalouden investoinnit ja tilojen talous - onko Suomen EU-jäsenyyden haasteisiin pystytty vastaamaan?
}

\author{
Erik Haggrén ja Matti Ylätalo
}

Taloustieteen laitos, PL 27, 00014 Helsingin yliopisto, Erik.Haggrén@Helsinki.Fi, Matti.Ylatalo@Helsinki.Fi

\section{Tiivistelmä}

Maatalouden asema maassamme on kokenut jatkuvasti suuria muutoksia. Vuoden 1995 alusta alkanut EU-jäsenyys toi mukanaan suuren haasteen. Siihen asti maatalous oli ollut suojattu ulkomaiselta kilpailulta, joten EU-jäsenyys merkitsi aivan uuden kilpailu- ja toimintaympäristön syntyä. Maataloustuotteiden hinnat laskivat välittömästi EU-tasolle. Viljelijöiden toimeentulon turvaamiseksi otettiin käyttöön uusi tukijärjestelmä, joka vastasi vanhoissa EU-maissa noudatettuja periaatteita. Keskeinen elementti EU-kauden tukijärjestelmissä on ollut investointitukien korostaminen tavoitteena nopeuttaa maatalouden rakenteen ja tulojen kehittämistä vanhoja EUmaita vastaavalle tasolle.

Tämän tutkimuksen avulla pyritään selvittämään, miten maatalous kokonaisuudessaan ja toisaalta eri tilaryhmät ovat selvinneet EU-jäsenyyden tuomista haasteista ennen jäsenyyttä ja sen aikana vuosina 1987-2004.

Tutkimuksessa on muodostettu laaja tilakohtainen aikasarja-aineisto, joka perustuu Tilastokeskuksen Maatalouden yritys- ja tulotilaston MYTT tietoihin. Niistä on muokattu yhtenäiset ja tilastollisesti edustavat, vuodet 1987-2000 kattavat aikasarjat, Tilastokeskuksen alkuperäinen aineisto perustuu otoksiin, joiden tilamäärä on laskenut vuoden 1987 noin 15000 tilasta koko maan tilaluvun laskun myötä vuoden 2000 noin 9000 tilaan.

Aikasarjoissa MYTT:in tilakohtainen perusaineisto on luokiteltu uudelleen EU-aluejakoa vastaavaksi koko ajanjaksolta. Tutkimusjakson ajalta kaikki markkamääräiset luvut on muutettu reaalisiksi, vuoden 2000 rahanarvoa vastaavaan tasoon kuluttajahintaindeksin avulla.

Tutkimuksessa tarkastellaan aluksi maatalouden kokonaiskehitystä tutkimusaineistosta saatavan osin uuden tietoaineiston pohjalta. Keskeisiä tarkastelun kohteita on tilaluvun, maataloustulon ja investointien kehitys kokoluokittain, tuotantosuunnittain ja EU-tukialueittain. Seuraavaksi on siirrytty tutkimaan maatalouden kehitystä tilatason näkökulmasta.

Viljelijöiden lukumäärän nopea väheneminen ja tilakoon kasvu ovat auttaneet nostamaan keskimääräisiä maataloustuloja, jotka ovat kasvaneet lähes kaikissa tuotantosuunnissa ja kaikilla alueilla. Poikkeuksena ovat olleet viljatilat ja A-alueen tilat keskimäärin. Kun maataloustulon keskimääräistä kehitystä tarkastellaan tilakokoluokittain eri tuotantosuunnissa ja EU-tukialueilla, niin tilanne muuttuu lähes päinvastaiseksi. Maataloustulo on tilakokoluokittain ja tuotantosuunnittain tarkasteltuna EU-jäsenyyden aikana vuosina 1995-2000 kasvanut vain 6 ryhmässä 25:stä. Selvästi suurinta kasvu on ollut yli 50 hehtaarin naudanlihatiloilla.

Yleensä investointien avulla pyritään tulojen lisäämiseen. Maataloudessa tämä strategia ei näytä onnistuneen kovinkaan hyvin edes suurilla tiloilla. Tulevaisuuden kannalta ratkaiseva kysymys onkin, mikä on riittävän suuri tilakoko vai täytyykö kasvua jatkaa loputtomiin? Tällöin ongelmaksi tulevat kestävän kehityksen periaatteet ja inhimilliset resurssit ainakin perheviljelmällä.

Asiasanat: maatalouden investoinnit, maataloustulo, maatalouden rakennekehitys, aikasarjat

\section{Johdanto}

Maatalouden asema maassamme on kokenut jatkuvasti suuria muutoksia. Vuoden 1995 alusta alkanut EU-jäsenyys toi mukanaan suuren haasteen. Siihen asti maatalous oli ollut suojattu ulkomaiselta kilpailulta, joten EU-jäsenyys merkitsi aivan uuden kilpailu- ja toimintaympäristön syntyä. Maataloustuotteiden hinnat laskivat välittömästi EU-tasolle. Viljelijöiden toimeentulon turvaamiseksi otettiin käyttöön uusi tukijärjestelmä, joka vastasi vanhoissa EU-maissa noudatet- 
tuja periaatteita.

Pitkään jatkuneesta voimakkaasta rakennekehityksestä huolimatta Suomen maatalous joutui kohtaamaan EU-jäsenyyden haasteet huonoista lähtöasemista. Maamme tuotantoyksiköt olivat keskimäärin yhä pieniä ja niiden taloudellinen kilpailukyky uudessa EU-jäsenyyden mukanaan tuomassa taloudellisessa toimintaympäristössä oli useimmissa tapauksissa heikko vanhoihin EUmaihin verrattuna.

Maataloudessa investoinnit ovat avainasemassa tuotantorakennetta kehitettäessä. Keskeinen elementti EU-kauden tukijärjestelmissä olikin investointitukien korostaminen tavoitteena nopeuttaa maatalouden rakenteen kehittämistä vanhoja EU-maita vastaavalle tasolle. Samalla tavoitteena oli kehittää viljelijäväestön tuloja EU:n yhteisen maatalouspolitiikan (CAP) periaatteiden mukaisesti ja parantaa viljelijäperheiden suhteellista asemaa lähemmäs muun väestön toimeentulotasoa.

Tässä esitelmässä tuodaan esiin Taloustieteen laitoksella suoritetun tutkimusprojektin eräitä keskeisiä tuloksia. Tutkimuksen avulla pyrittiin selvittämään, miten maatalous kokonaisuudessaan ja toisaalta eri tilaryhmät ovat selvinneet EU-jäsenyyden tuomista haasteista ennen jäsenyyttä ja sen aikana vuosina 1987-2005. Aluksi suoritettiin kokonaistason tarkastelu tilakokoluokittain, tuotantosuunnittain ja EU-tukialueittain. Erityisen mielenkiinnon kohteena oli maatalouden investointikehitys ja toisaalta maatalouden rakenteen ja viljelijöiden tulojen tarkastelu.

Seuraavaksi on siirrytty tutkimaan maatalouden kehitystä tilatason näkökulmasta. Tilojen eri kehityspiirteitä on tutkittu EU-jäsenyyden aikana ja niitä on verrattu ennen EU-jäsenyyttä toteutuneeseen kehitykseen. Tässä tarkastelussa on seurattu tilakeskiarvojen avulla kehitystä Suomessa keskimäärin sekä sen lisäksi eri EU-tukialueilla, tuotantosuunnissa ja tilakokoluokissa. Lopuksi tarkastellaan, miten käytettävissä olevan tutkimusaineiston avulla voidaan tutkia investointien vaikutuksia maatalouden rakenteeseen ja maataloustuloon.

\section{Aineisto ja menetelmät}

Tutkimuksessa on hyödynnetty aiemmissa Helsingin yliopiston taloustieteen laitoksen tutkimuksissa kertyneitä laajoja tilakohtaisia aikasarja-aineistoja ja täydennetty niitä saatavilla olevilla myöhempien vuosien tiedoilla (Sipiläinen ym. 1998). Näin saadaan yhtenäiset ja tilastollisesti edustavat, vuodet 1987-2000 kattavat aikasarjat, jotka perustuvat Tilastokeskuksen Maatalouden yritys- ja tulotilaston MYTT tietoihin. Tilastokeskuksen alkuperäinen aineisto perustuu verotustiedoista poimittuihin otoksiin, joiden tilamäärä on laskenut vuoden 1987 noin 15000 tilasta koko maan tilaluvun laskun myötä vuoden 2000 noin 9000 tilaan. Aikasarjoissa MYTT:in tilakohtainen perusaineisto on luokiteltu uudelleen EU-aluejakoa vastaavaksi koko ajanjaksolta. Maatalouden tulokehityksen tarkastelemiseksi jakson 1987-2000 aikana kaikki markkamääräiset luvut on muutettu reaalisiksi, vuoden 2000 rahanarvoa vastaavaan tasoon kuluttajahintaindeksin avulla. Vuosien 20012005 osalta tutkimuksen käytössä on ollut maataloustulon kehitystä koskevia vertailutietoja maatalouden kannattavuustutkimuksen kirjanpitotiloilta (MTTL tietokannat).

Tutkimuksen käytössä oleva verotusaineiston erityispiirteet asettavat omat rajoituksensa tutkimuksen toteuttamiselle. Maatalouden verotuksessa sovelletaan käytäntöä, joka perustuu käteiseli kassaperiaatteeseen. Sen mukaan tositteet merkitään verotusmuistiinpanoihin niiden maksuajankohdan mukaan. Näin pääosa tulo- ja menoeristä liittyy samaan vuoteen kuin maksutapahtumakin. Koska esim. maatalouden kannattavuuskirjanpidossa taas noudatetaan suoriteperustetta, eroavat eri aineistoista lasketut vuotuiset tulokset aina jonkin verran toisistaan.

Verotusaineiston avulla ei voida suoraan tutkia maatalouden kannattavuuden kehitystä. Tässä suhteessa suurin ongelma on se, että aineistossa ei ole lainkaan tietoja maatalouden kokonaispääomasta eikä viljelijäperheen omasta työpanoksesta. Sen vuoksi verotusaineiston pohjalta tehtävässä tutkimuksessa joudutaan tarkastelemaan kannattavuuden asemasta ensi sijassa maataloustulon kehitystä. Maataloustulon avulla on perinteisesti arvioitu myös kannattavuuskehitystä $\mathrm{mm}$. maatalousneuvotteluissa. Näin saatu kuva onkin suhteellisen luotettava tilaryhmäkohtaisessa ja koko maan kannattavuuskehityksen arvioinnissa, sillä työn ja pääoman suhteellisen osuuden vuotuiset muutokset ovat suhteellisen pieniä kun siirrytään tilatasolta suurempiin ryhmiin.

Verotuksessa ja tilastokeskuksen suorittamassa aineiston käsittelyssä on tutkimusjakson aikana tapahtunut runsaasti muutoksia, jotka on mahdollisuuksien mukaan otettu huomioon muo- 
kattaessa aineistoa yhtenäiseen aikasarjamuotoon. Tutkimuksen kannalta mielenkiintoiset muuttujat on jouduttu useimmissa tapauksissa konstruoimaan usean eri verotustiedon avulla. Esimerkiksi investoinnit ja maataloustulo on muodostettu seuraavasti:

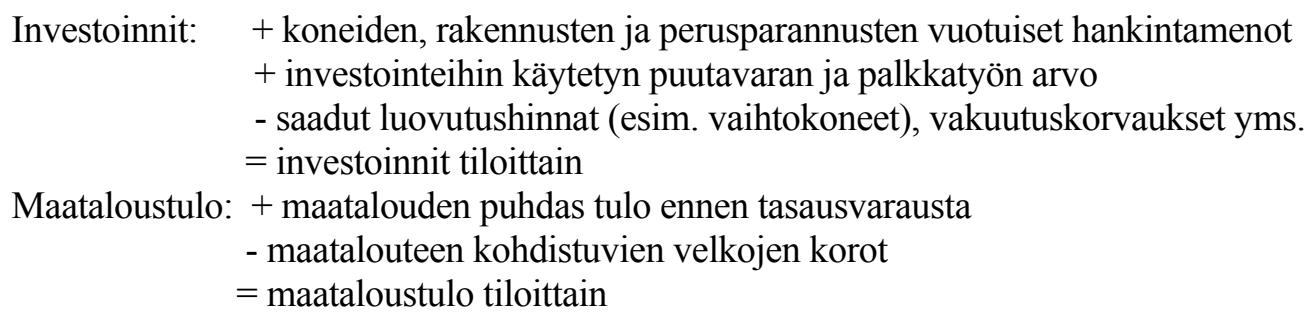

Tutkimuksen keskeisenä teoreettisena viitekehikkona on investointiteoria. Investointiteorian mukaan odotettavissa olevat tuotot ja kustannukset sekä investointiin liittyvät riskit ovat ratkaisevassa asemassa investointipäätöksiä tehtäessä. Investointien avulla pyritään parantamaan tulevaisuuden tulovirtaa ja yrityksen taloudellista asemaa. Kannattamatonta tai tappiollista investointia ei siis kannata tehdä edes runsasmittaisten investointitukien avulla. EU-jäsenyys lisäsi toisaalta riskejä ja epävarmuutta, jotka vähentävät investointihalukkuutta. Ongelmana on erityisesti maatalouden kannattavuuden lisääntynyt riippuvuus EU-poliitikkojen vaikeasti ennustettavista päätöksistä.

Lisäksi tutkimusta toteutettaessa lähtökohtana ovat olleet maatalouden yritystalouden ja kannattavuustutkimuksen peruskäsitteet ja niiden analysoinnissa käytetyt liiketaloudelliset tutkimusmenetelmät. Tutkimuksen käytössä ollut tilakohtainen aikasarja-aineisto, ns. paneeliaineisto, tarjoaisi hyvän lähtökohdan investointien ja tulojen vaikutussuhteiden tutkimiseksi myös ekonometristen mallien avulla. Tutkimuksessa on kuitenkin käytetty havainnollisempaa aikasarjakuvioihin perustuvaa tarkastelutapaa ja muut analyysit jätettiin mahdollisten jatkotutkimusten varaan.

Tilakokoon mukaan tehdyn luokittelun avulla voidaan arvioida ns. keskiarvoharhan vaikutusta tuloksiin, sillä sen avulla voidaan tarkastella verrata tuotantosuunnittain ja alueittain laskettuja tilaryhmien keskiarvoja erikokoisten tilojen kehitykseen.

\section{Tulokset}

\section{Investointien vaikutukset maatalouden rakenteeseen}

Maatalouden investoinnit ovat vaihdelleet syklisesti tutkimusjakson 1987-2000 aikana. Ennen EU-jäsenyyttä 1990-luvun alkupuolella investoinnit supistuivat voimakkaasti kaikissa tilaryhmissä ja maan kaikilla alueilla 1990-luvun alkupuolella. Tähän vaikuttivat sekä yleistaloudellinen lama että maatalouden kannattavuusnäkymien heikentyminen ja epävarmuuden lisääntyminen mm. EUjäsenyysneuvottelujen myötä. Keskimäärin tilakohtaiset investoinnit puolittuivat vuoden 1990 huipusta eli 40000 markan tasolta noin 20000 markkaan vuoteen 1994 mennessä. Suomen liityttyä EU:n jäseneksi vuoden 1995 alussa tilanne kääntyi päinvastaiseksi. Keskimääräiset investoinnit kasvoivat nopeasti 50000 markan tasolle vuoteen 2000 mennessä. Tähän vaikuttivat erityisesti EUtukijärjestelmien mittavat investointituet.

Tutkimuksen tulokset osoittavatkin selvästi, että investointien avulla on mahdollistettu maatalouden tuotantorakenteen voimakas kehittäminen tutkimusjakson aikana, sekä ennen EUjäsenyyttä että sen aikana. Tämä rakennekehitys on puolestaan mahdollistanut entistä tehokkaamman tuotannon ja periaatteessa tuotteiden yksikkökustannusten alentamisen. Samalla maatalouden päätuotteiden alueellinen painopiste on jonkin verran siirtynyt. Tämä tulee selvästi esiin maidon tuotannossa, jossa erityisesti C2-alueen tuotanto on kasvanut. Myös sianlihan ja viljan tuotanto on tilaosuuksien perusteella siirtynyt hieman pohjoista kohti C1- ja C2-alueille.

Maatilojen keskikoko on kasvanut voimakkaasti sekä ennen EU-jäsenyyttä että sen aikana. eri EU-tukialueilla ja eri tuotantosuunnissa. Koska investoinnit lisämaahan ovat usein tehokkain tapa tilan taloudellisen aseman parantamiseksi, niin rakennekehitys ilmenee usein juuri tilakoon kasvuna. Keskimääräinen tilakoko on vuosina 1988-2000 kasvanut 1,85-kertaiseksi eli lähes kaksinkertaistunut 15,3 hehtaarista 28,3 hehtaariin. EU-jäsenyyden aikana keskikoon kasvuvauhti on hieman nopeutunut, 5,3 prosentista 6,7 prosenttiin vuodessa. Kehityksen myötä tilojen lukumäärä 
on supistunut alle 30 ha:n tilakokoluokissa ja kasvanut tätä suuremmissa tilakokoluokissa. EUalueittain tarkasteltaessa keskipeltoalan suhteellinen kasvuvauhti on nopeutunut pohjoiseen siirryttäessä, mutta pohjoisempien alueiden pienempien keskipeltoalojen vuoksi eri alueiden väliset absoluuttiset erot ovat pikemminkin kasvaneet A-alueen hyväksi.

Tilaluvun laskun myötä keskipeltoala on noussut kaikissa tuotantosuunnissa. Suurin keskikoko on perinteisesti ollut sikatiloilla. EU-jäsenyyden aikana niiden kasvunopeus on ollut selvästi nopeampaa kuin ennen jäsenyyttä. Toiseksi suurin keskikoko vuonna 2000 oli maitotiloilla, jotka olivat ohittaneet tutkimusjakson alussa toisella sijalla olleet viljatilat maan kaikilla alueilla. Tilojen keskikoko kasvoi tutkimusjakson aikana nopeimmin naudanlihatiloilla ja vuonna 2000 niiden keskikoko oli kolmanneksi suurin. Viljatilojen keskikoko kasvoi muita tuotantosuuntia selvästi hitaammin ja on vähitellen jäänyt eri kotieläintiloja pienemmäksi.

\section{Maataloustulon kehitys tuotantosuunnittain, EU-tukialueittain ja tilakokoluokittain}

Tässä tutkimuksessa keskimääräistä maataloustulon kehitystä on tarkasteltu eri tuotantosuunnissa, EU-tukialueilla ja tilakokoluokissa. Viljelijöiden lukumäärän nopea väheneminen ja tilakoon kasvu ovat auttaneet nostamaan keskimääräisiä maataloustuloja, jotka ovat kasvaneet vuoteen 2000 asti lähes kaikissa tuotantosuunnissa (kuvio 1.) ja kaikilla alueilla (kuvio 3.). Poikkeuksena ovat olleet viljatilat ja A-alueen tilat keskimäärin. Vuodesta 2001 alkaen keskimääräinen maataloustulo näyttäisi kuitenkin kääntyneen laskuun kaikissa tuotantosuunnissa maatalouden kannattavuustutkimuksen kirjanpitotiloilta saatujen tietojen mukaan. Eri tuotantosuunnista naudanlihan tuotanto on selvinnyt parhaiten ja vilja heikoimmin (kuvio 1.) sekä koko tarkastelujaksolla että myös EU-jäsenyyden aikana. EU-tukialueista A- ja B-alueet näyttäisivät olevan häviäjiä, kun taas C2- ja C1-alueet ovat menestyneet muita paremmin (kuvio 3.). Suuret tilat ovat parantaneet suhteellisia asemiaan kuten ennenkin (kuvio 2.), vaikka EU:n tukijärjestelmä ei suosikaan niitä.

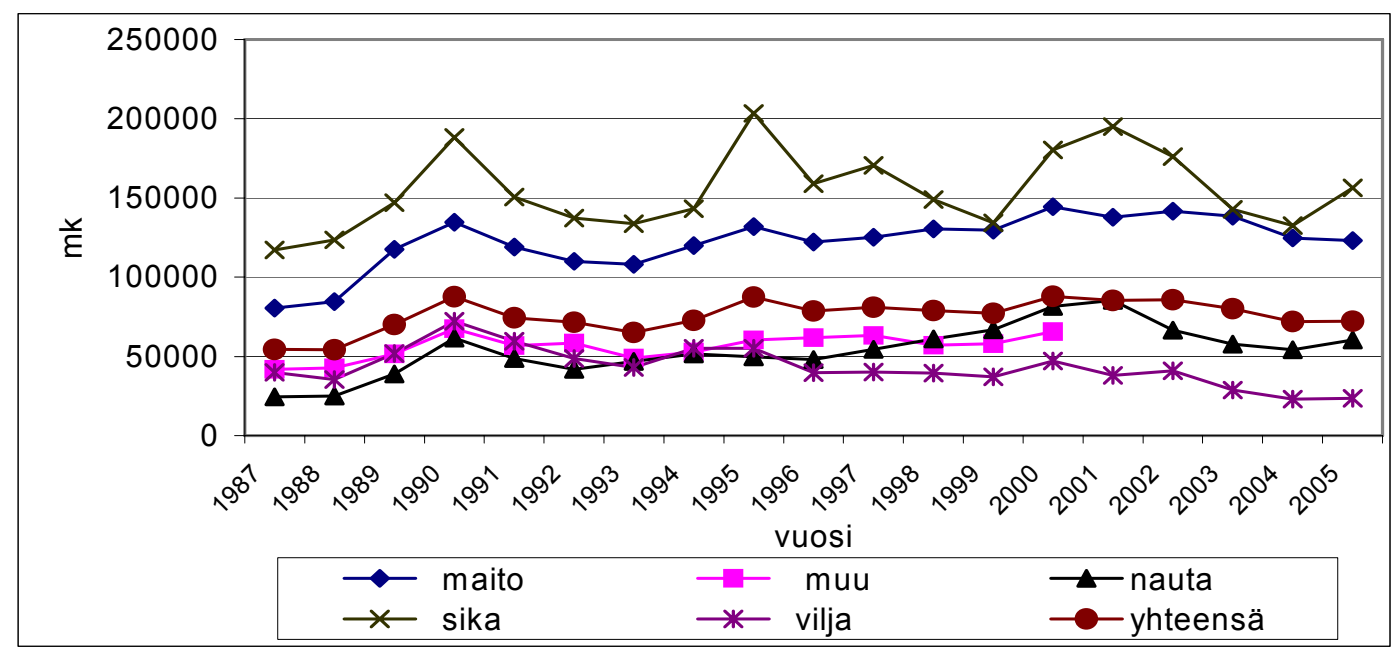

Kuvio 1. Maataloustulo eri tuotantosuunnissa vuosina 1987-2000, mk/tila. Vuosien 2001-2005 tiedot on johdettu suhteellisina Maatalouden kannattavuuskirjanpitotilojen tiedoista, vuodet 2004 ja 2005 ennakkotietoja (MTT taloustutkimus tietokannat).

Tulokehityksestä saadaan aivan toisenlainen kuva kun asiaa tarkastellaan eri tilakokoluokis-

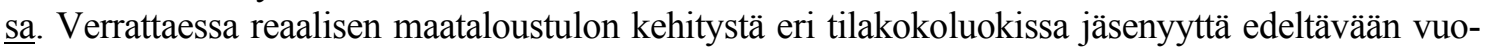
teen 1994 ovat tulot alentuneet voimakkaasti pienissä tilakokoluokissa ja suurimmillakin tiloilla ne ovat pysyneet lähes ennallaan ( kuvio 2.), vaikka keskimääräiset tulot ovat samaan aikaan kasvaneet voimakkaasti. Maataloustulon keskimääräisen kehityksen tarkastelu johtaa siten helposti harhaiseen käsitykseen toimintaansa jatkavien tilojen tulokehityksestä. Tosiasiassa tuotannosta luopuvien pienten tilojen poistuminen tilastoista ei vaikuta suoranaisesti jatkavien tilojen maataloustuloon, vaikka tilastoista laskettu maataloustulon keskiarvo nousee selvästi.

Tutkimuksessa tarkasteltiin myös erikseen yli 30 hehtaarin tiloja, joiden keskimääräinen maataloustulo EU-alueittain on esitetty kuviossa 3. Nämä tilat jatkavat todennäköisimmin tuotantoaan. Vuon- 
na 2000 niiden osuus kaikista tiloista oli jo lähes kolmasosa, joten ne vastannevat pääosaa 10 vuoden päästä jäljellä olevista tiloista. Kuvion 3. mukaan yli 30 hehtaarin tilojen keskimääräinen maataloustulo on vaihdellut voimakkaasti ilman selvää kehityssuuntaa. EU-kaudella se on pysynyt käytännössä jäsenyyttä edeltäneen vuoden 1994 tasolla 157580 mk. Selvä poikkeus on vain EU:n jäsenyyden alkuvuosi 1995, jolloin maksettiin EU:n korvaukset ennen jäsenyyttä tuotettujen varastojen arvonalennuksesta.

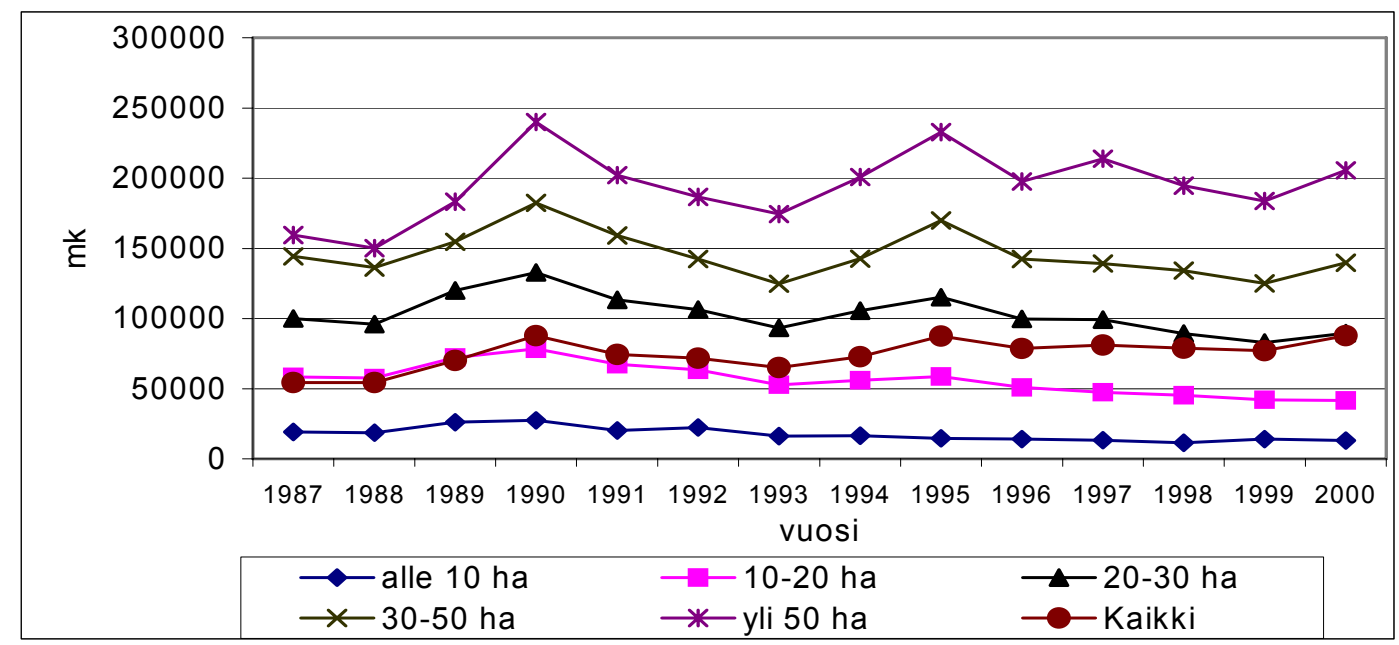

Kuvio 2. Maataloustulo kaikilla tiloilla kokoluokittain vuosina 1987-2000, mk/tila

Suurten tilojen maataloustulon tarkastelu EU-tukialueittain tuo esille eräitä mielenkiintoisia pitkän aikavälin kehityskuvia. Jo kansallisen maatalouspolitiikan aikana tuloerot eri alueiden välillä olivat tasoittuneet. EU-kauden aikana eri alueiden kehitystrendit ovat jatkuneet ja eri alueiden järjestys on tuloerojen uudelleen kasvaessa muuttunut päinvastaiseksi. EU-aikana pohjoisemmilla suurilla tiloilla onkin ollut korkeampi maataloustulo kuin eteläisemmillä tiloilla.

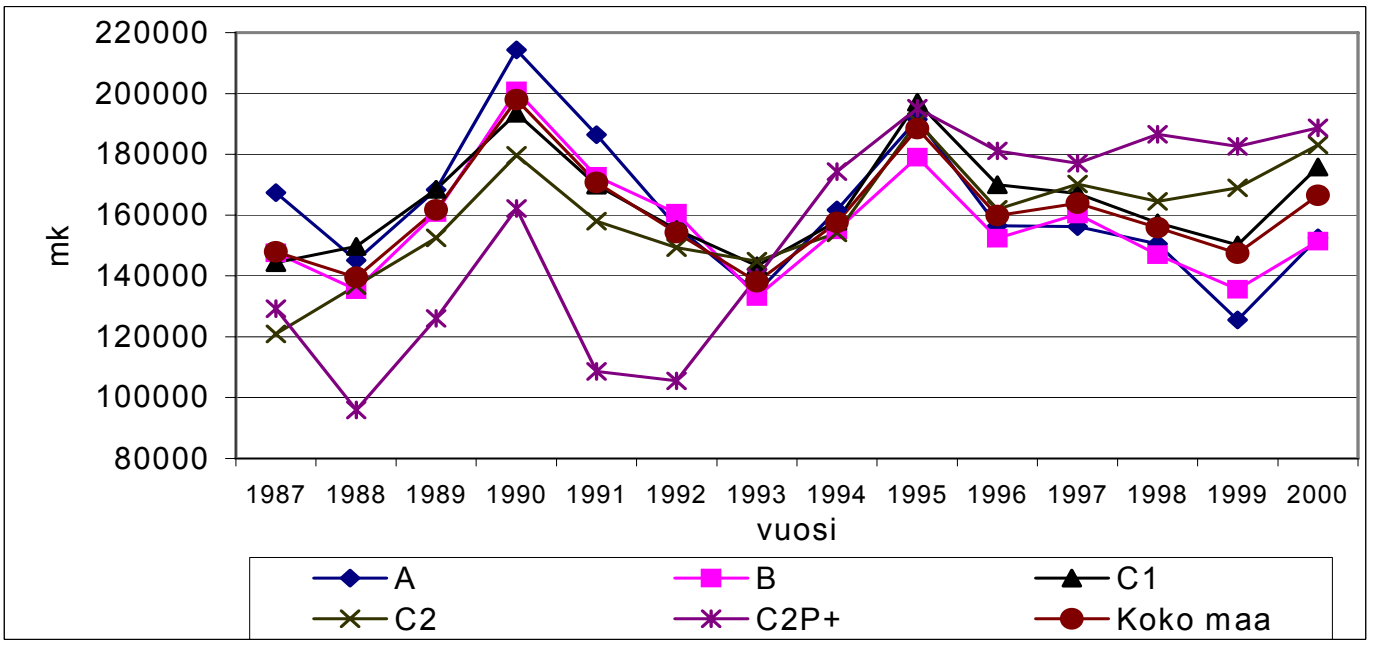

Kuvio 3. Suurten yli 30 ha:n tilojen maataloustulon kehitys EU-tukialueittain vuosina 1987-2000

Alueittaisten tulotasojen tarkastelu osoittaa, että Suomessa maatalouden alueellisia tuloeroja on tasoitettu tehokkaasti sekä ennen EU-kautta että myös sen aikana. Näin luonnonolosuhteiden aiheuttamat erot maan eri osien maatilojen tuloasemassa ovat vähitellen kompensoituneet hinta- ja tukipolitiikan vaikutuksesta. EU-aikana tukipolitiikka on ratkaisevassa asemassa, koska hinnat ovat nykyään lähellä toisiaan eri alueilla.

Suurten tilojen heikon tulokehityksen aiheuttama ongelma korostuu yläpäästään rajoittamattoman yli 50 hehtaarin kokoluokan kohdalla (kuvio 4.). Avoimessa kokoluokassa tilojen keskikoko kasvaa rakennekehityksen myötä syntyvien entistä suurempien yksiköiden vaikutuksesta. Tämä- 
kään vaikutus ei ole auttanut nostamaan suurimpien tilojen keskimääräistä tulotasoa, mikä on ollut kuitenkin investointien tavoitteena. Nämä tulokset osoittavat käytännössä todeksi myös sen, että EU:n tukijärjestelmät eivät keskimäärin suosi yrittäjyyttä, tehokkuutta ja suuria tiloja.

\section{Investointien vaikutus maataloustuloon}

Investointien vaikutuksia viljelijäväestön tulotasotavoitteiden saavuttamiseen on vielä ongelmallisempaa arvioida kuin niiden vaikutuksia rakennemuutoksiin. Kun verrataan hyvin ja huonosti menestyneiden tilaryhmien investointien kehitystä, niin voidaan todeta parhaiten selviytyneiden tilaryhmien usein myös investoineen eniten, mutta aineistossa on päinvastaisiakin esimerkkejä. Lisäksi myös tässä tulee esille suhteellisten ja absoluuttisten vertailujen ero. Eri tuotantosuunnista parhaiten menestyneiden naudanlihatilojen keskimääräiset investoinnit kasvoivat EU-kaudella 4,12-kertaisiksi ja maataloustulo 1,58-kertaiseksi. Kuitenkin tilakokoluokittain tarkasteltaessa vastaavat luvut jäävät paljon vaatimattomammiksi. Esimerkiksi pienillä 10-20 hehtaarin naudanlihatiloilla investoinnit ovat kasvaneet selvästi voimakkaammin 2,58-kertaisiksi, mutta maataloustulo on kuitenkin supistunut lähes 30 prosentilla.

Tarkasteltaessa maataloustulon kehitystä tilakokoluokittain eri tuotantosuunnissa se on EU-jäsenyyden aikana kasvanut vain 6 ryhmässä 25:stä. Selvästi suurinta kasvu on ollut yli 50 hehtaarin naudanlihatiloilla $(1,63)$. Seuraavana olivat alle 10 hehtaarin sikatilat $(1,56)$, joilla myös investointien kasvukerroin oli suurin 4,56. Kolmanneksi sijoittuneilla 30-50 hehtaarin naudanlihatiloilla kerroin oli 1,25. Samanaikaisesti niiden investoinnit ovat kasvaneet 2,66-kertaiseksi, mikä on ollut neljänneksi voimakkainta mm. yli 50 hehtaarin maitotilojen $(3,09)$ jälkeen.

Jos taas tarkastellaan eri tuotantosuunnissa niitä voimakkaimmin investoineita ryhmiä, joiden maataloustulo on kuitenkin laskenut EU-jäsenyyden aikana, niin silmiinpistävin esimerkki on yli 50 hehtaarin maitotilat. Niiden investointien kasvu 3,09-kertaiseksi on ollut toiseksi voimakkainta, mutta maataloustulo on alentunut 15 prosenttia EU-kautena.

Kun maataloustulon ja investointien kehitystä verrataan eri EU-alueilla ja tilakokoluokissa, niin voidaan todeta maataloustulon kasvaneen EU-jäsenyyden aikana vain 5 ryhmässä 25:stä. Kaikki nämä ryhmät kuuluvat C-alueiden yli 30 ha:n ryhmiin. Parhaiten ovat menestyneet noin 10 prosentin kasvuun ovat päässeet $\mathrm{C} 2$-alueen 30-50 hehtaarin tilat ja yli 50 hehtaarin tilat sekä C2P+ alueiden 30-50 hehtaarin tilat. C1-alueen kaksi suurinta tilakokoluokkaa ovat päässeet parin prosentin kasvuun. Näiden viiden ryhmän investointien kasvukertoimet ovat vaihdelleet välillä 1,86-2,29 lukuun ottamatta $\mathrm{C} 2 \mathrm{P}+$-alueen 30-50 hehtaarin tiloja, joilla kerroin oli vain 1,15. Sitä vastoin tämän alueen yli 50 hehtaarin tiloilla maataloustulo on laskenut EU-jäsenyyden aikana 13 prosenttia, vaikka investoinnit olivat kasvaneet 3,85-kertaisiksi.

Kokonaisuudessaan näyttää siltä, että yksittäisten ryhmien kohdalla investointien ja maataloustulon kehityksellä ei näiden lukujen perusteella ole ollut selvää yhteyttä monessakaan tapauksessa. On kuitenkin otettava huomioon, että investointien vaikutukset tulevat aikaisempien tutkimusten mukaan esiin vasta verrattain pitkällä viiveellä, usein vasta 5-10 vuoden jaksolla investointien teon jälkeen (Haggrén ym.1988). EU-jäsenyyden aikainen voimakas panostus investointitukiin ei kuitenkaan ainakaan vielä näy maataloustulon kasvuna muutamaa poikkeusta lukuun ottamatta.

\section{Vertailu viljelijöiden ja palkansaajien tulojen välillä}

Tutkimuksen lopuksi on rakennettu vertailuasetelma, jossa tarkastellaan yli 30 hehtaarin tilojen ja palkansaajien tulojen suhteellista kehitystä. Vertailuasetelma viljelijöiden ja palkansaajien välillä on monelta osin ongelmallinen. Kuviossa 4. on esitetty palkansaajien yleisen ansiotasoindeksin elinkustannusindeksiin suhteutettu reaalinen kehitys siten, että indeksin perusvuoden 1994 arvoksi on asetettu 100, kuten kaikilla yli 30 ha:n tiloilla. Kuvion käyrät kuvaavat siis maataloustulon suhteellista kehitystä eri ryhmissä verrattuna palkansaajiin, eivätkä siis absoluuttisia tulotasoja. Kuviosta näkyy, miten palkansaajien reaalitulot ovat kasvaneet suhteellisen tasaisesti runsaan yhden prosentin vuosivauhtia 1990 luvun alun lamaa lukuun ottamatta.

Keskimäärin kaikkien yli 30 hehtaarin tilojen keskimääräinen maataloustulo on EUkaudella pysynyt käytännössä jäsenyyttä edeltäneen vuoden 1994 tasolla 157580 mk (kuviossa 2. 
pisteluku 100) maataloustulolle ominaisia vuotuisia vaihteluita lukuun ottamatta. Tarkasteltaessa erikseen 30-50 hehtaarin ja yli 50 hehtaarin tiloja havaitaan, että myös molempien suuria tiloja edustavien tilakokoluokkien maataloustulo on pysynyt ennallaan tai ollut trendinomaisesti lievässä laskussa.

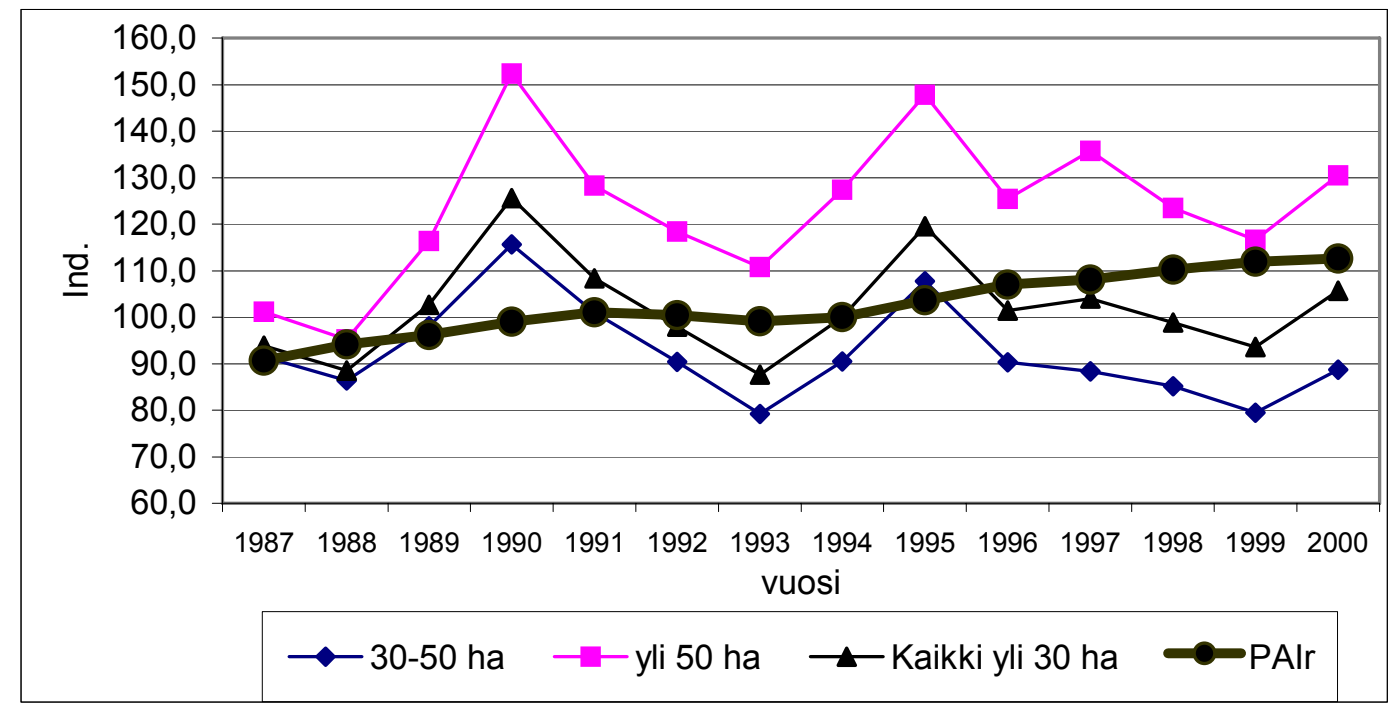

Kuvio 4. Maataloustulon kehitys yli 30 ha:n tiloilla vuosina 1987-2000 verrattuna palkansaajien ansiotasoindeksin reaaliseen kehitykseen $(1994=100$, palkansaajien yleinen ansiotasoindeksi ja kaikki yli 30 ha:n tilat vuonna 1994=100)

\section{Johtopäätökset}

Tutkimuksen käytössä ollut laaja perusaineisto on antanut mahdollisuuden tutkia maatalouden kehitystä ennen EU-jäsenyyttä ja sen aikana varsin perusteellisesti ja monipuolisesti. Tulokset antavat uutta tietoa siitä, miten EU-jäsenyyden haasteisiin on pystytty vastaamaan. Erityisesti EU-aluejaon ulottaminen myös jäsenyyttä edeltävään aikaan on tuonut esiin aivan uuttaa tietoa alueellisesta kehityksestä.

Tulosten mukaan näyttää kuitenkin siltä, että investointien keskeinen tavoite, tulojen ja kannattavuuden paraneminen, on useimmiten ollut hyvin vaikeasti saavutettavissa ja lisäksi jatkuvasti karkaamassa käsissä. Vain jatkuvasti kasvava tila näyttäisi pystyvän parantamaan jatkuvasti kannattavuuttaan ja tulojaan, mutta käytännössä tämä on hyvin vaikeasti noudatettavissa oleva ja useimmiten mahdoton strategia. Pysähtyminen tiettyyn kokoluokkaan on merkinnyt koko EUjäsenyyden ajan myös tulokehityksen pysähtymistä harvoja poikkeuksia kuten isoja naudanlihatiloja lukuun ottamatta. Aivan viime vuosina näidenkin tilanne on heikentynyt. Kuitenkin ilman voimakkaita investointeja rakennekehitykseen tilanne olisi ilmeisesti vielä paljon huonompi.

Yleensä investointien avulla pyritään tulojen lisäämiseen. Maataloudessa tämä strategia ei näytä onnistuneen kovinkaan hyvin edes suurilla tiloilla. Tulevaisuuden kannalta ratkaiseva kysymys onkin, mikä on riittävän suuri tilakoko vai täytyykö kasvua jatkaa loputtomiin? Tällöin ongelmaksi tulevat kestävän kehityksen periaatteet ja inhimilliset resurssit ainakin perheviljelmällä.

\section{Kirjallisuusluettelo}

Haggrén, E., Pyykkönen, P. \& Ylätalo, M. 1988. Valtion rahoitustukea saaneiden viljelmien pitkän aikavälin taloudellinen kehitys. Pellervon taloudellisen tutkimuslaitoksen raportteja ja artikkeleita $75.60 \mathrm{~s}$.

Haggrén, E. 2005. "Maatalouden investoinnit ja tilojen talous vuosina 1987-2000 - kehitys ennen EUjäsenyyttä ja sen aikana". Helsingin Yliopiston taloustieteen laitos. Saatavissa tekijältä.

MTTL. Maatalouden taloudellisen tutkimuslaitoksen tietokannat.

Sipiläinen,T., Ryhänen, M, Ylätalo, M., Haggrén, E., \& Seppälä.E., 1998. Maatalousyritysten talous vuosina 1993-2002. -EU-jäsenyyden vaikutus tuloihin ja kannattavuuteen. Summary: The Economic Outcome of Finnish Farms - The Effects of the EU-membership on Farm Income and Profitability. Helsingin yliopisto, Taloustieteen laitos, Julkaisuja 18. 